\title{
mEiEa
}

\section{The Asian Music Industry}

\author{
Don Cusic \\ Belmont University \\ This paper was presented at the 2019 International Summit of the \\ Music \& Entertainment Industry Educators Association
}

March 21-23, 2019

https://doi.org/10.25101/19.16

\section{Abstract}

Three nations-Japan, South Korea, and India-dominate the Asian music industry with a fourth, China, ready to become the dominant music industry in Asia. There are major differences between the countries. Japan has the second largest music industry in the world based on generated revenues; it is only behind the United States. However, Japan has fought the trend of digital streaming and remains heavily into high-priced physical product. Japan's music industry is protected, protective, and insular; it does not seek to export its music and is happy with Japanese music for Japanese consumers. South Korea, on the other hand, with its K-Pop industry is intent on exporting its artists and recordings. Three agencies dominate K-pop and those agencies find talent, groom the talent, then set them out into the world. India's music industry relies heavily on films; the major exposure of music comes from India's Bollywood films. Although there are streaming services in India, the film industry dominates the music industry.

China was known for its piracy of American recordings, which was a huge wall against China having a legitimate music industry. However, with the advent of streaming, the Chinese are able to exert control over their industry and, with their large population, reach billions. One of the major emerging firms with digital streaming is Tencent, which is headquartered in China. There are barriers to China's rise as a major music center, primarily their censorship of anything they dislike. China wants Chinese music to go out into the world but doesn't want the world's music to infiltrate China. Whether they can balance all of these ideas will determine the future of China's music industry.

Keywords: Asian music industry, Japanese music industry, South Korean music industry, Indian music industry, Chinese music industry, K-pop, Tencent
The Asian Music Industry is centered on Japan, South Korea, India and China. In 2017, there was an overall growth in the region of 5.4 percent. Streaming revenues increased by 38.2 percent. Digital revenues increased by 22.4 percent - and this is the way the music industry as a whole is headed, although there are still strong physical sales in Japan and South Korea.

Major labels plan to release only in the digital format in Asia except for Japan and South Korea. This is a "solution" to piracy, which has plagued the industry for years.

Japan has been the second biggest market for the music industry for years. Japan accounts for 56 percent of the overall market for physical recordings in Asia and 91 percent of music industry recordings in Japan are physical.

Overall, 25 percent of music industry revenue in Asia comes from streaming. If you remove Japan, then 20.4 percent of music industry revenues come from physical recordings while 59.9 percent comes from streaming.

In the United States and other developed countries, we have seen a progression in the recording industry of people buying - and listening on - phonographs, then cassettes to the Walkman to the CD player to the desk computer to the laptop to the iPod to mobile (brick) phone to flip phones to smart phones. In most Asian markets, they have gone from the cassette to the smart phone.

Now let's take a look at the countries individually. In Japan, the second largest market for recording industry sales - behind the United States - they sell more physical product than any other market. They have not been plagued by piracy like other markets. Since 2012 they have one of the strongest anti-piracy laws in the world. It is a criminal offense to pirate recordings and, if convicted, a person will have to pay two million yet and spend up to two years in jail. Also - they rent CDs, so a Japanese consumer can rent a $\mathrm{CD}$ and then load it onto their computer before they return it to the store. This is a major reason that CD piracy is almost non-existent in Japan.

CDs are expensive: 3,000 yen or approximately $\$ 30$. Most of the CDs have "bonus content," which means it may include photo booklets, cards of favorite performers, offers to buy tickets for concerts, and sometimes a DVD. A single 
costs 250 yen or US\$2.50.

There is no discount selling in Japan-it is illegal to sell a CD for less than $\$ 25$ so there is no competition among retailers discounting prices. A major reason that Japan generates so much money from their entertainment industry is that prices are high - the most expensive entertainment in the world. The government and the entertainment industry work to keep it that way.

The most popular promotion for a single is an offer to vote for which members of a group get promoted to the front of the group and sing their next single. DVDs may cost as high as US\$100. A ticket to a movie is 1,800 yen or approximately $\$ 18$. Most of the revenue is generated in cash; the average Japanese consumer uses their credit card only four times a year.

There are streaming services in Japan-Line is the most popular although Spotify, Apple Music, Google Play Music, and Amazon Prime are available. However, no streaming service has music from all the labels in Japan - there are agreements where one record company licenses its catalog to one streaming service while another record company licenses its product to a different streaming service. In order to have all Japanese music available, you have to pay for several streaming services. Line music is integrated with the Line messaging app, and this linking of streaming and messaging is popular in other Asian countries. With Line, a user can send cartoons, emoticons, music, and playlists.

Japan does not market its artists globally; they view their domestic market as their major market. The most popular group in Japan is AKB48.

The "360 deal" is prevalent in Japan. The agencies-recruit and train artists - provides artists with financial support while the artists give the label a percent of total revenue they generate, such as income from concerts, publications and appearances. Most artists are on salary from their agency.

Not many listen to radio. In Japanese cars there are television on the dashboard.

South Korea music became globally known because of "Gangnam Style" by PSY. However, those in South Korea insist that PSY is not K-pop. The roots of K-pop go to Lee Soo-man, a former folk singer who left South Korea in 1980 after a military coup. He went to the United States and received a Masters from California State, Northridge. He loved MTV and when he moved back to South Korea in 1985, wanted to re-create American pop music in Korea.

The democratization of South Korea is linked to the 1988 Olympics in Seoul. That led to a market-based economy. In 1989, Lee founded SM Entertainment.

After one of his artists was arrested on drug charges, he decided to find and create pop singers. This was like what Lou Pearlman did with the Backstreet Boys and NSYNC in the United States. Lee called his method of creating groups "cultural technology" and laid out the steps to popularize pop groups. Lee's manual of "cultural technology" states when to import foreign composers, producers, and choreography; what chord progressions to use in particular countries; the precise color of eye shadow a performer should wear in different Asian regions; the hand gestures he or she should make; and camera angles to be used in the videoswhich meant a 360 degree group shot to open the video, followed by a montage of individual close-ups.

During the late 1990s, a "Korean wave" swept through Asia: TV dramas, Korean films, and K-pop became popular. This coincided with the "Asian crisis" when the real estate bubble burst, leading to a deep recession. Korean TV producers made shows cheaper than Japan and Hong Kong with better quality than most Asian nations could afford.

The image of South Korea had been a country that was unsophisticated, a weak industrial nation. There were estimates it would take 100 years for South Korea to recover and catch up. However, Korean entertainment created images of a prosperous, cosmopolitan country and music fans in Japan and Hong Kong became fans of K-pop.

$\mathrm{K}$-pop is dominated by three Seoul agencies: SM Entertainment, JYP, and YG Entertainment. The groups are all tightly controlled by their agencies, which include a record company, manager, agent, and promoter who control record sales, concerts, publishing, endorsement, and TV appearances by the young idols. The agencies form groups by recruiting boys and girls ages 12 to 19 through auditions and a network of scouts. The members do not have to come from South Korea. The recruits are coached in singing and dancing as well as media coaching during training that lasts years before they are placed in a group. The young applicants are not paid during their training. Only ten percent are finally chosen to be in a group.

Scandals of any sort result in expulsion from a group. Agencies have studios and in-house producers and songwriters create the songs for the groups. Generally, an album is released every 18 months with five song min-albums annually. The groups seldom last more than five years. The appeal of the acts is linked to their beauty: members often have plastic surgery. This formula did not create PSY.

Koreans prefer Korean music-over 80 percent of the music industry is Korean acts. Under ten percent prefer American pop music. In Korea, 37 percent of the revenue from their music industry comes from physical product; 59 percent is from streaming.

Some factors in the success of K-pop: The Korean government has created the most wired and wireless nation on the planet. There are more mobile phones than there are people. The most popular mobile phone brand is Samsung, based in South Korea. The cost of a download was 
five cents, although downloads are decreasing globally. The $\mathrm{K}$-pop strategy is to export their artists to the world.

The music industry in India is dominated by Bollywood. Bollywood films are primarily musicals and the songs are sung by professional singers while the actors lip synch, usually while dancing.

The internet infrastructure has held back development in India but in 2016 Reliance Industries launched the Jio mobile network, which offers free $4 \mathrm{G}$ coverage. This has led to an increase in music streaming.

In China, a turning point came in July 2011 when companies agreed to an out of court settlement to pay for music tracks played and downloaded. There is still piracy in China, but this has curbed it. The result is that China now has a legitimate music industry and in 2017 became one of the top ten music markets in the world. The majority of revenue comes from digital; streaming accounts for 90 percent of industry revenue.

The Chinese have developed their own search engine, Baidu, an e-commerce company; Alibaba, which is bigger than Amazon; and mobile messaging service WeChat that is compared to Facebook but does much more than Facebook. For example, through WeChat Chinese consumers can shop on line, pay utility bills, pay for taxis, theater tickets, and dinners.

The biggest music industry digital company is Tencent, which rivals Google, Apple, Facebook and Amazon. Tencent has several streaming services, including QQ music, Kugou, and Kuwo. They sublicense music to Alibaba Music, the Taihe Music Group, Changba, Apple, and KKBOX. China Mobile is the state owned telecom company. The Universal Music Group has its catalog distributed by Tencent.

There is censorship: the Culture Ministry of China has to authorize the release of any recordings. They must also approve of any foreign touring acts, who must submit a list of songs they intend to play. Until the 1980s, most Chinese did not know about rock music. Beginning in 1989, Beijing Music Radio played rock, blues, and jazz for the first time on Chinese radio.

The IFPI forecasts a tremendous increase in streaming revenue. The leading local media network, Vkontakte, had been a notorious copyright infringer. However, in 2017 they launched with licensed music services and streaming partners include Apple Music, Yandex, and Zvooq.

The trends in the global music industry include: a "tenacious decline" in physical; a top down move to digital - no $\mathrm{CD} / \mathrm{DVD}$ players on new laptops or CD players in new cars; and growth in "smart speakers".

In China, millions have moved into the middle class during the past 25 years and there is now an enforcement of copyright and intellectual property laws in non-developed countries. The major trend in the global music industry as well as the global economy and politics is that China wants to dominate the world.

Don Cusic is the author of over thirty books. He founded and taught the course "International Music Business" at Middle Tennessee State University and Belmont University. He has taught short-term study abroad courses in London, Japan, South Korea, and China.

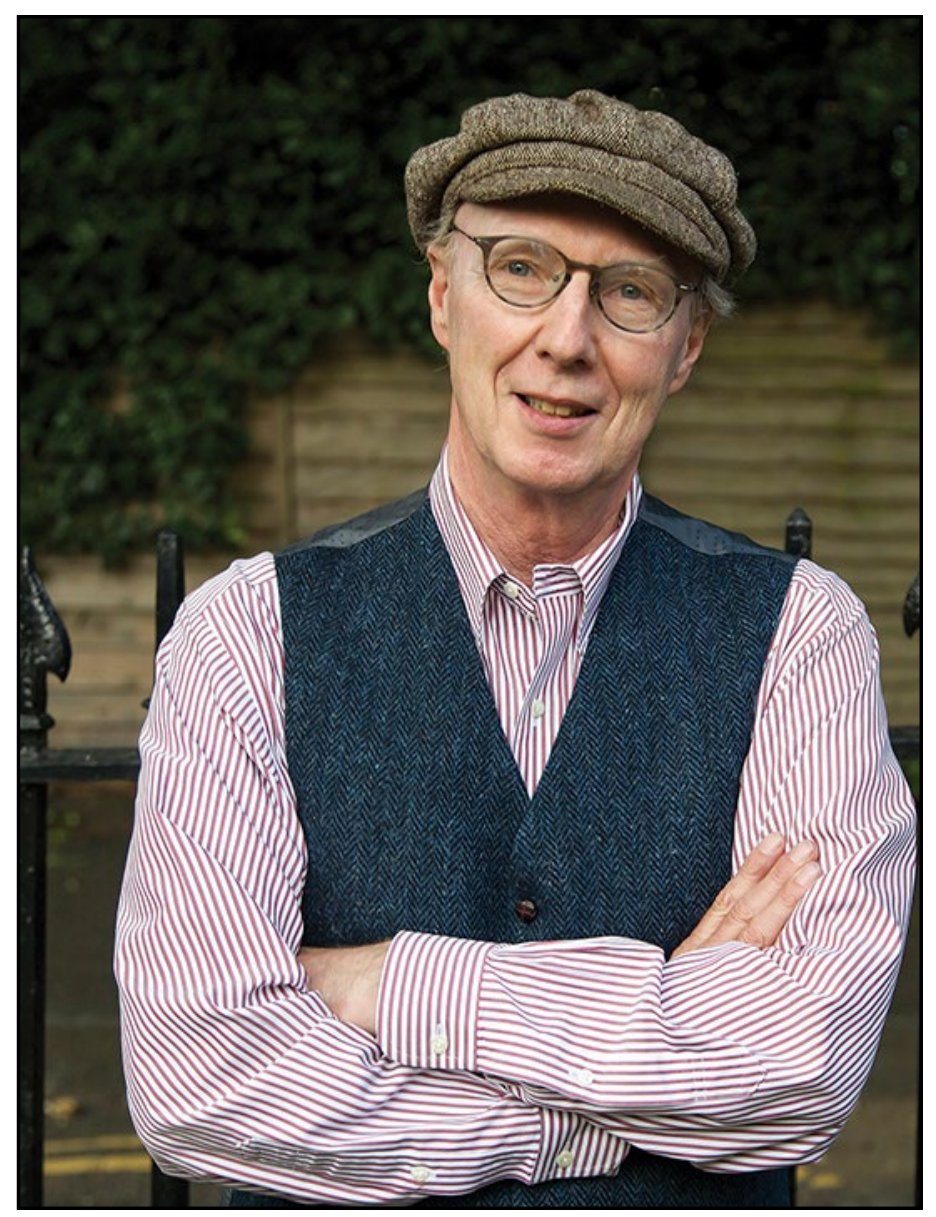




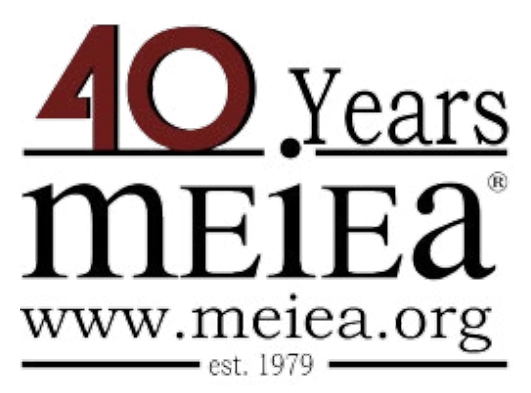

\section{PROCEEDINGS OF THE \\ 2019 INTERNATIONAL SUMMIT \\ OF THE \\ MUSIC \& ENTERTAINMENT \\ INDUSTRY EDUCATORS \\ ASSOCIATION}

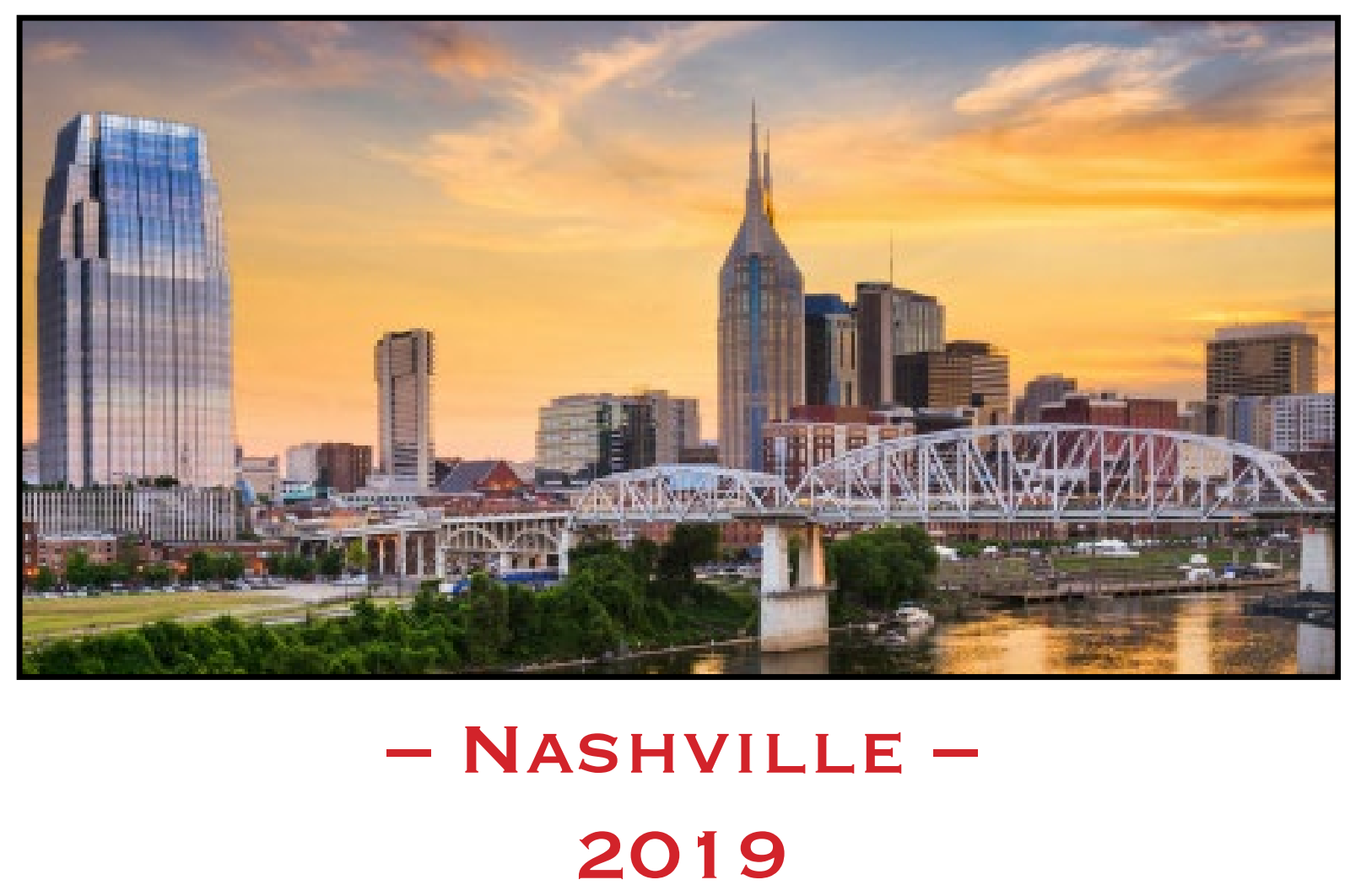

March 21 - 23, $2019 \cdot$ Belmont University - Nashville 